\title{
Impact of local knowledge endowment on employment growth in nanotechnology
}

by Antje Schimke, Nina Teichert, Ingrid Ott

No. 38 | FEBRUARY 2012

\section{WORKING PAPER SERIES IN ECONOMICS}

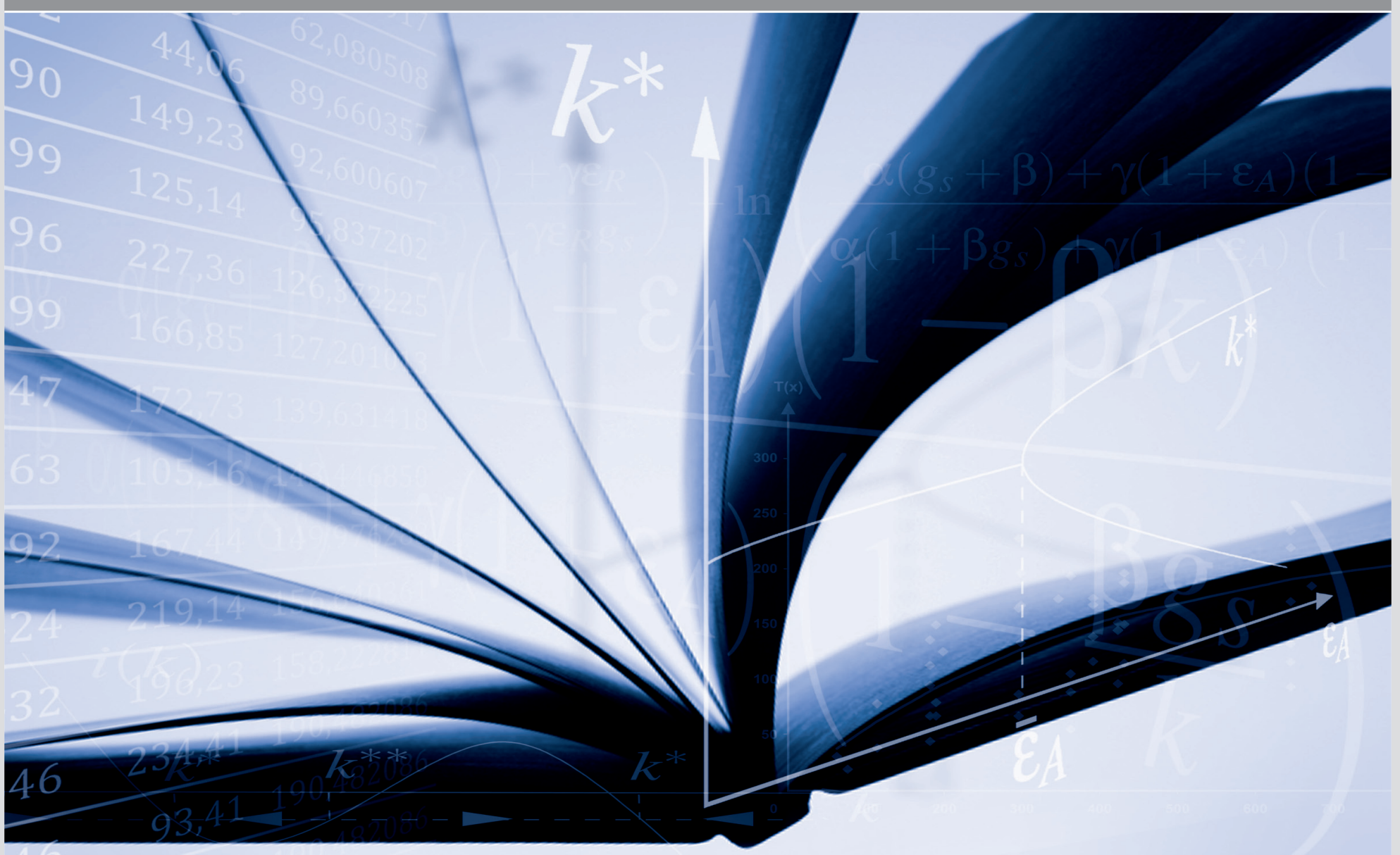




\section{Impressum}

Karlsruher Institut für Technologie (KIT)

Fakultät für Wirtschaftswissenschaften

Institut für Wirtschaftspolitik und Wirtschaftsforschung (IWW)

Institut für Wirtschaftstheorie und Statistik (ETS)

Schlossbezirk 12

76131 Karlsruhe

KIT - Universität des Landes Baden-Württemberg und nationales Forschungszentrum in der Helmholtz-Gemeinschaft

Working Paper Series in Economics

No. 38, February 2012

ISSN 2190-9806

econpapers.wiwi.kit.edu 


\title{
Impact of Local Knowledge Endowment on Employment Growth in Nanotechnology
}

\author{
Antje Schimke*\$, Nina Teichert*, Ingrid Ott*
}

February, 2012

\begin{abstract}
This paper investigates the contribution of local knowledge endowment to employment growth in nanotechnology firms. We exploit a unique data set focusing on firms operating in fields that apply nanotechnology. Our findings suggest that regions that offer knowledge can stimulate employment growth in smaller and younger firms. By contrast, being embedded into specialised regions might be counterproductive, especially for firms belonging to a particularly knowledge intensive sector and older firms.
\end{abstract}

Key words: Employment growth, local knowledge endowment, general purpose technology, specialisation, nanotechnology, spillover

JEL codes: $\quad$ D83, L25, O31, R11 


\section{$1 \quad$ Introduction}

All over the world nanotechnologies are seen as the most promising future technology with a great economic potential for growth and employment. The term nanotechnology thereby refers to most different types of analysis and processing of materials which have one thing in common: Their small size $(1-100 \mathrm{~nm})$. Nanotechnology makes use of the special characteristics that many nanostructures do not only depend on the original material but very much also on their size and shape. It is widely accepted as being the next general purpose technology (e.g. Youtie et al. 2008).

Nanotechnology is still a young and dynamic technology, there is large scope for improvement, and innovation activities are essential firm activities. In Germany, small and mediumsized enterprises (SME) account for more than $80 \%$ of all nanotechnology firms (SchnorrBäcker 2009). Due to fragmented R\&D and production processes, most of the firms only provide parts of complex value creation chains while being embedded in various networks. As a consequence of their high innovation intensity, the anchorage of the actors within regional specialisations is central. One general expectation concerning the overall role of nanotechnology firms is their contribution to job generation thereby strengthening regional competitiveness. It is reasonable to assume that the characteristics of the economic surrounding feed back to nanotechnology firms' performance and vice versa.

Along this line of reasoning this paper addresses the impact of two economic key characteristics of nanotechnologies and their potential for job creation and growth: As

the usual arguments in the context of the proximity-productivity relationship, i.e. the linkages between innovation, spillovers and economic performance also apply to nanotechnologies. Especially important are hence not only firm specificities but also a sufficiently specialised surrounding to translate spillovers to actual productivity gains. Key determinants are thus a sufficiently high overlap of firms' activities (absorptive capacity) as well as the availability of qualified labour. Consequently, the actors' regional anchorage and especially the composition of regional labour markets are central determinants of success.

In contrast to this is the

of nanotechnologies, which basically allows introducing the technology in any context. This implies that a certain degree of regional specialisation is not mandatory per se, but, depending upon the state of development of the technology, even the contrary may the case: Too narrow regional specialisation patterns may inhibit the technology's use in a multitude of application fields, thereby possibly suppressing potential opportunities for cross-fertilisation and innovation-enhancing feed-back mechanisms across diverse and so far unrelated value creation chains.

This is the starting point of the paper at hand. It addresses two major questions: (i) (How) do firm-specific and location-specific characteristics interact and influence the process of job creation of nanotechnology firms?, and (ii) What is the impact of regional specialisation in this context? Put differently, which characteristic of nanotechnologies predominates: its character as a high technology (i.e. being located in a sufficiently specialised region thereby benefitting from regional (knowledge) spillovers is of major importance) or the character as a general purpose technology (according to which opportunities aside from already existing specialisations may be more important for firm success)? The empirical analysis is based on an online survey carried out 2011 among German nanotechnology firms. The regional levels are German Raumordnungsregionen, i.e. official statistical units used in Germany lying between NUTS2 and NUTS3. We apply a two-step regression approach starting with OLS and subsequently followed by a fixed-effect panel regression in order to analyse how nanotechnology 
firms' employment growth is affected by both firm-specific and location-specific determinants. In doing so, we especially link the analysis to existing specialisation patterns. Our main results may be summarised as follows: Location of nanotechnology firms matters for employment growth. However, the relative importance of the degree of specialisation of the economic surrounding decreases in favour of diversification. This might be interpreted as an indication of the relevance of the general purpose character of nanotechnologies. The remainder of the paper is as follows: In Section 2 we supply the theoretical background and derive our main hypotheses (section 3). Section 4 introduces our methodology and data. In section 5 we present our results and interpretations and section 6 briefly concludes.

\section{$2 \quad$ Related Literature}

There is a vast literature on firm growth referring to sales, revenues, or employment. Most prominent determinants underlying the analyses are the characteristics of the firm (e. g. size, age, industry affiliation, financing strategy), of the entrepreneur (e. g. education, skill distribution), or firm location (e. g., Storey (1994) for an overview). Related theories range from neoclassical considerations on optimal size (Coase 1937), over internal learning-by-doing processes (Penrose 1995) and evolutionary concepts in which the 'fitness' of firms plays a central role (e.g. Coad 2007) to the socio-economic view which highlights the importance of resource availability and the competition for these resources (e.g. Uhlaner et al. 2007). Empirical findings suggest that there is not one single key determinant driving firm growth but the result is highly context specific and depends upon the interaction of several influencing factors (e. g. Harhoff et al. 1998, Delmar et al. 2003, Coad 2007).

Independent of the studied determinants, country or sector, the literature unambiguously highlights the positive relationship between innovative activity and firm growth (e.g. Acs and Audretsch 1988, Del Monte and Papagni 2003, Adamou and Sasidharan 2007, Harrison et al. 2008 or Coad and Rao 2008). The studies also stress the overall importance of employment and the availability of qualified labour for innovation (e.g. Acs and Audretsch 1990, Pianta 2005, López-García and Puente 2009).

Feldman (1994) or more recently Feldman and Kogler (2010) provide evidence that especially innovative activity tends to cluster thereby pointing to the importance of specialisation; at the same time several studies show that firms in clusters reach higher levels of innovation (e. g. Moreno et al. 2004, Fromhold-Eisebith and Eisebith 2005). Of special interest are the characteristics of local knowledge thereby suggesting that specialised local knowledge has a particularly positive effect on innovation and firm growth (Feldman and Audretsch 1999). Fritsch and Slavtchev $(2008,2010)$ also confirm that innovating firms are not isolated, self-sustained entities but rather highly linked to their environment. Location matters since it may provide access to specialised networks of firms, suppliers, institutions, or labour (see also Porter 2000; more critically Martin and Sunley 2003). Other arguments discussed in the context of clustering include stronger pressure to innovation or lower costs for innovation commercialisation (Ketels 2009). Spillover opportunities and thus the proximity-productivity linkage decrease with distance, as knowledge that is highly contextual most frequently requires interaction and face-to-face contact (von Hippel 1994).

However, until recently there are only few studies that analyse the role of location and the proximity-productivity relationship for post-entry performance, i.e. the growth of firms (e.g. Gabe and Kraybill 2002, Boschma and Weterings 2005, Audretsch and Dohse 2007, Weterings and Boschma 2009). We contribute to this literature by extending the basic question of the impact of specialised local knowledge endowment (both and ). In do- 
ing so our research focuses on nanotechnology firms' growth. This is particularly challenging since this young technology is not only innovation and therefore knowledge intensive but is also coined by a general purpose character. Thus, the relationship between regional specialisation and firm growth is not per se clear in the discussed context.

Our paper is most closely related to Audretsch and Dohse (2007) who find that regions abundant in knowledge resources provide a particularly fertile soil for the growth of young, technology-oriented firms. They consider new market firms and point to the need of investigating the relationship between local knowledge endowment and firm performance in other high and emerging technologies. Our unique data-set on German nanofirms allows us to test their main hypotheses in the promising field of nanotechnology. While Audretsch and Dohse (2007) only elaborate on the influence of the accessible stock- and hence the quantity - of local knowledge, we extend the analysis to the and hence the quality of the local knowledge base. Besides, we test the robustness of our hypotheses by two different econometric approaches and introduce novel measures that expand their explanatory power.

\section{Derivation of Hypotheses}

Following the argumentation above, we propose the natural expectation that location does affect the growth of firms in nanotechnologies. We moreover assume that employment growth in nanotechnology firms is strongly related to successful innovative activity. Following Feldman (1994), knowledge spillovers are especially relevant for small firms since the resources necessary in order to maintain the knowledge base are typically beyond their means. This suggests that the extent to which external knowledge is crucial and can be absorbed differs widely across different firm size classes and knowledge intensive sectors. Paying attention to the characteristics of the structure of the region a firm is located in and the knowledge processing characteristics of the firm itself, we hypothesise that:

Put differently, we hence suppose that regions rich in knowledge provide a particularly good environment for the growth of technology-oriented, i.e. knowledge intensive firms. Taking into account the peculiarities of nanotechnologies as GPT and the interaction with the characteristics of location, the arguments suggest that specialisation might not be conducive for the employment growth of firms that are active in the exploration of general purpose nanotechnologies since this hampers the inflow of knowledge from other fields and even suppresses positive effects stemming from diversity and nanotechnologies' application in a wide variety of fields. Catalysing knowledge recombination and fertilising ideas from other application fields most presumably cannot be processed in an environment with a single focus. However, firms experience a tension when they aim to advance and exploit existing knowledge and at the same time explore new fields simultaneously (Leten et al. 2007). Specialisation is neces- 
sary to develop sufficiently strong capabilities in particular domains in order to be able to realise economies of scale in technology development while incrementally advancing the technology. Hence, specialisation might have a positive effect on growth in nano-firms: Firms that are not particularly intensive in knowledge are assumed to rather exploit existing knowledge. We therefore separate the analyses again. The smaller and the younger a firm is, the more we assume it to be prone to specialisation externalities due to the fact that small firms are often highly specialised and enter the market via specialised niches (van der Panne 2004). Since the exploration of the field is intensive in knowledge we moreover assume that knowledge intensive, exploring firms are particularly benefiting from diversity and hence specialisation might have a negative impact.

Given the GPT nature of nanotechnology and the chances that are inherent in diversity and exploration of the field and on the other hand the minimum degree of knowledge in the respective field needed to be able to keep up with leading edge development, we assume that too less and too much regional specialisation negatively influence firm performance in either of the firm classes we distinguished.

Finally, we analyse the robustness of the impact of specialisation and location characteristics on employment growth. Thus, we investigate whether the yearly changes of the level of specialisation might interfere with the yearly changes in the growth rates. In this context, we hence more technically assume that

The expected results will sharpen our understanding of the association between concentrated activity of firms and the corresponding performance in the field of nanotechnologies as an emerging GPT. They may serve as a starting point for regional policy aiming at the improvement of the regional factors influencing the growth of firms in growth-promising nanotechnologies.

\section{$4 \quad$ Methodology and Data}

\subsection{Data Source}

In our unique data set, we focus on firms operating in fields that apply nanotechnology, irrespective of whether this is their main field of activity. These firms are not only knowledge intensive by operating in a high-tech sectors, but particularly because nanotechnologies are still in a nascent stage of development and hence these firms are intensive in innovation which is by definition knowledge intensive. Our data set of firms consists of records from the 'competence atlas nanotechnology in Germany' (www.nano-map.de), an online database providing information on firms that are concerned with nanotechnologies. We then conducted an 
online survey in 2011, asking the firms for information on employment numbers for different years, profits, year of foundation, zip code and their industry affiliation (i.e. NACE classification of the 2-digit and 3-digit industry affiliation) on the basis of their main products. This is particularly necessary since nanotechnology as GPT do not constitute a single industry, but are present in a wide range of different industries. 216 of 1950 contacted firms answered, which gives a response rate of 11.1 percent. To ensure whether our firm sample is representative of the entire population, we run a t-test for the two groups of interest. The independent samples t-test compares the difference in the means from the two groups to a given value (usually 0). In this vain, we split our firm sample into two groups: (i) response at an early stage and (ii) response at a later time. In doing so, we compare the two groups in regard to their number of employees and profits. Thereby, group (ii) stands for the firms that will never provide a response. In the case of the number of employees, the t-statistic is 1.1866 . The corresponding two-tailed $\mathrm{p}$-value is $0.2371>0.05$, i.e. non-significant. We therefore conclude that the mean difference of the two cohorts is not different from 0 . In the case of profits, the $t-$ statistic is -0.9374 and $p$-value is $0.3499>0.05$, again non-significant. The t-test statistics obviously show that there are neither in the case of number of employees nor in the case of profits significant differences between the two groups, which might lead us to the fact that our firm sample is representative of the entire population.

The level of analysis within our survey is the geographical level of planning regions ('Raumordnungsregionen'). Germany consists of 97 planning regions. This level is chosen as it is particularly suited to approximate spatial and functional interrelations between core cities and the corresponding hinterland (BBR 2001). Therefore, they are homogeneous and comparable entities, which are large enough to assume that spillovers are intraregional and hence no connection between the different regions has to be included in our estimations (Audretsch and Dohse 2007). It has to be mentioned that the nano-firms in our sample are not equally distributed: Out of the 97 planning regions, the nanotechnology firms in our sample are located in 62 different regions, some of them hosting a multitude of firms ${ }^{1}$. Figure 1 displays this distribution.

Figure 1: Distribution of Answering Nano-Firms across Germany

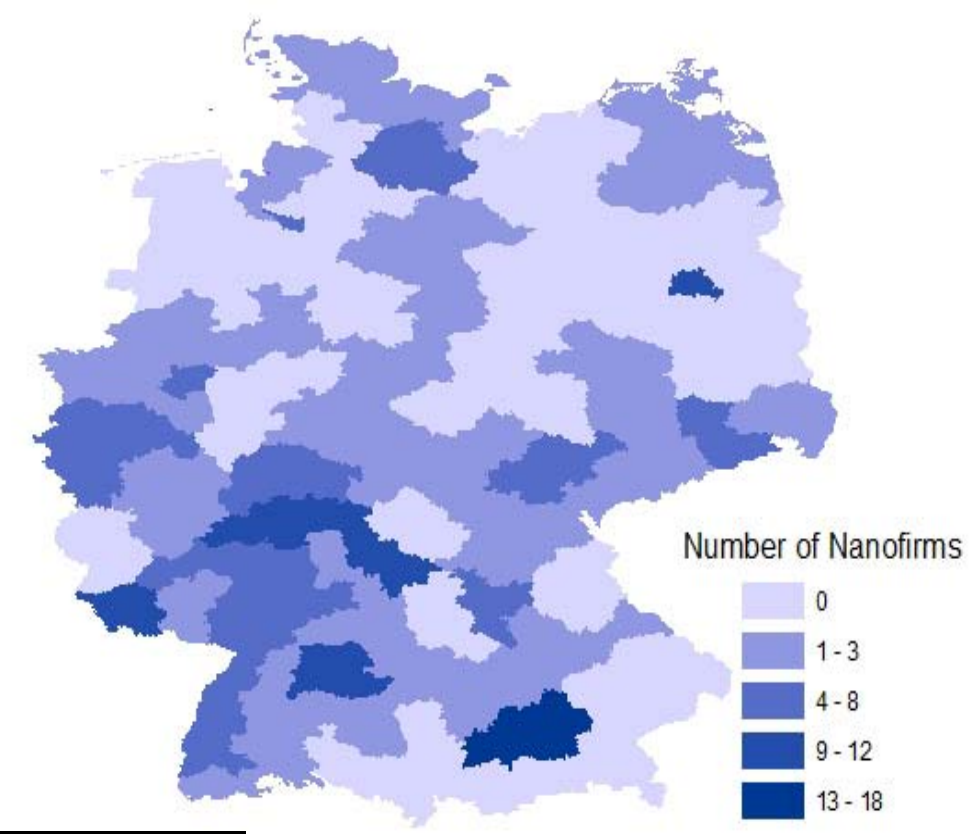

${ }^{1} 62$ different regions: avg.: 3.8 max: 18 and min: 1 


\subsection{Dependent Variable}

Before starting with the regressions, an operationalisation of the term firm growth is necessary. There is a wide range of definitions that deal with firm growth. Garnsey et al. (2006, p. 11) suggest that "firms' growth can be measured in terms of input (e.g. employees), in term of value of the firm and in terms of output (e.g. turnover, profit)". In our analyses, we use the growth measure of the growth of employees. We hence define our dependent variables by measuring the log-form of employment growth as the ratio of the year $t$ (respectively 2010) to year t-1 (respectively 2007). The year of the financial crisis, 2008, was replaced by the mean value. It might be that the stochastic properties of the growth rates exhibit a significant different behaviour. Furthermore, an appropriate replacement of the missing values is a neighbouring non-missing value (i.e. [n-1] or [ $\mathrm{n}+1])^{2}$ for each individual firm in the panel. Nevertheless, in some cases number of employees is completely missing for all years. Hence, we are not able to replace these missing values.

\subsection{Explanatory Variables}

Regarding our hypotheses, we employ several independent variables. These variables display firm-specific and location-specific characteristics. The firm-specific variables reflect rather usual factors found to influence employment growth, such as firm size, age and industry affiliation. Location-specific variables by contrast shall reflect the knowledge characteristics that are specific to the environment the firm is located in. An overview of the description of explanatory variables is given in Table 1 and the independent variables are discussed as follows:

$$
\text { fi }
$$

The -dummy controls for the size of the firm, as smaller firms more intensively and more frequently rely on knowledge spilling over for generating new knowledge and innovative activity than larger firms (Audretsch 1998). We hence assume small and medium-sized firms $(=1)$ to benefit differently from location-specific characteristics than larger ones (SIZE $=0$ ). is an industry-dummy, indicating whether a firm belongs to a particularly knowl-

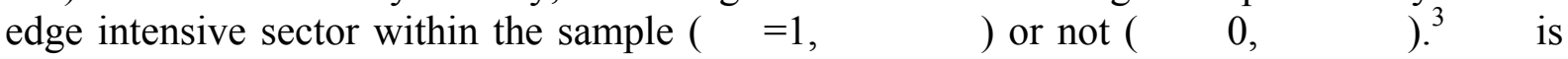
constructed by the share of 'knowledge workers' in an industry's labour force, which is measured by the share of employees with a university degree. Sectors with an above-average share of knowledge workers are hence seen as knowledge intensive (see Audretsch and Dohse 2007). We use this dummy in order to be able to distinguish between firms that are operating in above average knowledge-intensive industries among our sample of firms and hence especially prone to knowledge spillovers as positive externality raisinf their productivity. Moreover, - firms should be able to better incorporate, i.e. to use the knowledge that is spilling over as it is widely accepted that firms that are themselves active in knowledge processing and production exhibit a high absorptive capacity (Cohen and Levinthal 1990). We expect location hence to have a more relevant, positive influence on firms. We investigate whether firm age ( ) is an initial trigger for firm growth in nanotechnology. Age is consistently found to be a relevant impact factor on firm performance (Coad 2010). Since

\footnotetext{
${ }^{2}$ by id (year), sort: replace employees $=$ employees_n-1] if employees $>=$. / by id (year), sort: replace employees $=$ employees[ $\mathrm{n}+1]$ if employees $>=$.

3 Although it is natural to assume most of the firms in nanotechnologies to be intensive in knowledge as nanotechnologies definitely are considered as high-tech, this is not what we expect from our data. We surveyed firms that are processing nanotechnologies in which way whatsoever. Subsequently it might well be that the main activity of the firm is not in a high-tech sector.
} 
we assume that the impact of local knowledge characteristics on firm growth depends on firm characteristics, we use the modal age of the firms in our sample as cut-off point for creating a subsample of young and older firms each.

The location-specific variables refer to the role of locations, particularly to possible knowledge spillovers generated in the region. With we introduce a region-dummy referring to whether a region exhibits a share of highly qualified ( ) employees in the top quartile, measured by employees with university degrees. The variable, by contrast, displays employment in the firms' industry. In both, the and we hence implicitly assume that the regional human capital displays the regional knowledge resources, which is commonly done, as knowledge can be considered as incorporated in individuals who are able to process it (Rigby and Essletzbichler 2002). ${ }^{4}$ The distinction between these two variables is useful, as the dummy is a relatively general measure of knowledge intensity in the region, whereas is more specialised, pointing to the actual strength of the firm's industry in the considered region. We expect both to have a positive influence on firm growth. by contrast is a catch-all region-specific variable catching agglomeration effects in general by displaying the industry density of a region to improve model fit. A further standard measure capturing regional knowledge resources is the presence of a university in a region, as universities are at the same time supportive and necessary for regional innovation and economic development (Feldman and Kogler 2010). Research results are open to the public and ready to be exploited as knowledge spillovers. We therefore employ the number of students knowledge spillovers to increase with available knowledge resources, positive impact on firm growth. A similar argumentation holds for . Since we expect should have a in a region. The knowledisplaying the share of employees mainly concerned with in a region. The knowledge inherent in and produced by human capital (mainly) concerned with is likely to be another source of knowledge spillovers. The specialisation Location Quotient variable measures region-specific knowledge-resources and refers to the characteristics of the knowledge within a region. It is constructed using employment data, corresponding to the industry in which the firm operates. is calculated by the ratio of the share of employees of a region in this industry, divided by the total share of employees in this very field in the whole country:

$$
L Q_{i, j}=\frac{\frac{\text { Employees in region inindustry } j}{\text { Employeesin Germanyin industry } j}}{\frac{\text { Employeesin region } i}{\text { Employees in Germany }}} .
$$

indices are usual measures for specialisation externalities (Paci and Usai 1999). For the empirical analysis we employ a standardisation, making the index symmetric and easier to interpret by using the formula $\quad\left(\mathrm{LQ}^{2}-1\right) /\left(\mathrm{LQ}^{2}+1\right)$, which constrains possible values within the interval $(-100,100)$. Values above 0 hence indicate an above average, values below 0 below average specialisation. Following our hypotheses, we expect to influence the growth of firms. Table 1 pictures the different explanatory variables and a short description of variables. In general, we distinguish between firm-specific characteristics (SIZE, AGE and KIS) and locations-specific characteristics (HQ, INDDENS, IND, STUD, R\&D and LQ).

\footnotetext{
${ }^{4}$ We hence subsequently treat human capital as proxy for knowledge resources, bearing in mind the remark by Audretsch and Dohse (2007), that, although the interpretation of the average level of human capital in a region proxying local knowledge resources as part of the local firm's productions function is straightforward it remains still abstract, as it lacks a mechanism by which human capital actually contributes to higher growth (see also Rauch 1993).
} 
Table 1: Description of Explanatory Variables

\begin{tabular}{|c|c|c|c|}
\hline Category & Variable & Description & Nature \\
\hline \multirow{3}{*}{ 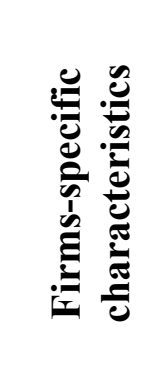 } & & $\begin{array}{l}\text { Small and medium enterprises, defined as those } \\
\text { with less than } 251 \text { employees ( } \mathrm{SME}=1 \text { ). }\end{array}$ & $\begin{array}{l}\text { subsamples and } \\
\text { control variable }\end{array}$ \\
\hline & & $\begin{array}{l}\text { Firms in sectors with an above-average share of } \\
\text { employees with university degree are knowl- } \\
\text { edge intensive (KIS }=1 \text { ). }\end{array}$ & $\begin{array}{l}\text { subsamples and } \\
\text { control variable }\end{array}$ \\
\hline & & $\begin{array}{l}\text { Age of the firm in terms of years since founda- } \\
\text { tion. Cut-off point used to distinguish between } \\
\text { young and old firms is modal age. }\end{array}$ & $\begin{array}{l}\text { subsamples and } \\
\text { control variable }\end{array}$ \\
\hline \multirow{6}{*}{ 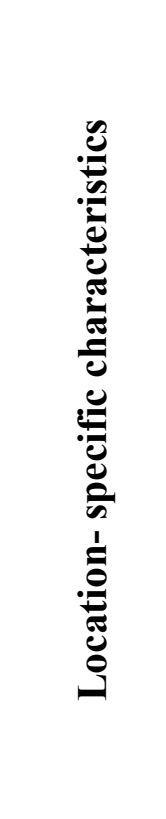 } & & $\begin{array}{l}\text { Region exhibits a share of highly qualified em- } \\
\text { ployees with university degree in the top quar- } \\
\text { tile. }\end{array}$ & $\begin{array}{l}\text { independent vari- } \\
\text { able }\end{array}$ \\
\hline & & $\begin{array}{l}\text { Measures industry density (employees in indus- } \\
\text { try per } \mathrm{km}^{2} \text { ) in a region, catchall variable for } \\
\text { agglomeration effects. }\end{array}$ & $\begin{array}{l}\text { independent vari- } \\
\text { able }\end{array}$ \\
\hline & & $\begin{array}{l}\text { Absolute employment in the firms' industry, } \\
\text { pointing to the actual strength of the firm's in- } \\
\text { dustry in the considered region. }\end{array}$ & $\begin{array}{l}\text { independent vari- } \\
\text { able }\end{array}$ \\
\hline & & $\begin{array}{l}\text { Absolute number of students in the considered } \\
\text { region. }\end{array}$ & $\begin{array}{l}\text { independent vari- } \\
\text { able }\end{array}$ \\
\hline & & $\begin{array}{l}\text { Absolute number of employees in } \mathrm{R} \& \mathrm{D} \text { in the } \\
\text { considered region. }\end{array}$ & $\begin{array}{l}\text { independent vari- } \\
\text { able }\end{array}$ \\
\hline & & $\begin{array}{l}\text { LQ is calculated by the ratio of the share of } \\
\text { employees of a region in this industry, divided } \\
\text { by the total share of employees in this very } \\
\text { field in the whole country. }\end{array}$ & $\begin{array}{l}\text { independent vari- } \\
\text { able }\end{array}$ \\
\hline
\end{tabular}

\subsection{Descriptive Statistics and Stochastic Properties}

The final database consists of 216 firms. The descriptive statistics for the employed variables are given in Table A2 (in the appendix). In respect to the different stochastic properties of the entire sample, the variables $\quad{ }^{5}$ are hence used to distinguish between the different subsamples. Table 3 shows the number of firms differentiated by different firm size classes. Firms classified as SME are defined as those with less than 251 employees (European Commission 2003). Obviously, SME firms are overrepresented in our sample. However, this is in line with the overall distribution of firms across size regardless of their technological background: SMEs are always overrepresented. More particularly, nano-firms are mostly SMEs and more seldom larger firms (Schnorr-Bäcker 2009), which is why our sample represents the population well. Table 3 moreover shows the share of firms differentiated (i.e. the most knowledge intensive sectors) and (i.e. younger and older firms). Additionally, Table 3 pictures that our sample consists of an above average number of firms active in knowledge intensive sectors ( ). Finally, we distinguish our sample between younger and older firms. The cut-off point in terms of younger and older firms is represented by the modal age of eight years (Fagiolo and Luzzi 2006, Huergo and Jaumandreu 2004a,b). In this vain,

\footnotetext{
${ }^{5}$ A majority of previous research tends to emphasise that younger firms exhibit higher growth rates than their larger counterparts (Jovanovic, 1982) and firm growth decreases with firm age (Acs and Mueller 2008, Coad 2010). In this context, the discussion on different age groups becomes apparent. A challenging task is still the cut-off point in terms of younger and older firms.

${ }^{6}$ The firms in our sample operate on 10 different nanotechnology fields: avg.: 2.1 max: 7 and min: 1 .
} 
the distinction between different age groups provides additional information on the growth process.

Table 3: Firm-specific Characteristics

\begin{tabular}{cllll}
\hline Category & Subsample & Description & Frequency & Percentage \\
\hline \multirow{2}{*}{ SIZE } & SME & $1 \leq \mathrm{x} \leq 250$ & 144 & 66.6 \\
& Large-sized & $>250$ & 72 & 33.4 \\
\cline { 2 - 5 } & High-KIS & Above average share of R\&D employ- & 178 & 82.4 \\
\multirow{2}{*}{ KIS } & (KIS=1) & ees & & \\
& Low-KIS & Below average share of R\&D employ- & 38 & 17.6 \\
& (KIS=0) & ees & 42 & 19.5 \\
\cline { 2 - 5 } AGE & Younger & $\leq 8$ years (modal age) & 174 & 80.5 \\
& Older & $>8$ years (modal age) & & \\
\hline
\end{tabular}

*Measure based on Audretsch and Dohse (2007).

** Cut-off point in terms of younger/older firms: Modal age of 8 years since foundation.

\subsection{Regression Approach and Model Fit}

First, we set up a regression approach using OLS estimation (see equation (1) and (2)) to analyse the average growth of firm. As independent variables all the described variables are used. We use the standard regression approaches since it can be expected that our residuals are approximately normally distributed. There is no evidence for a deviation from a normal distribution in our data. We also do not find other problems, such as heteroscedasticity for our regressions with the logarithm of relative growth as dependent variable. Reynolds et al. (1994) and more recently Audretsch and Dohse (2007) developed an estimation approach that includes location-specific determinants of growth, which we will build on for investigating whether firm growth in nanotechnology is affected by different location-specific characteristics. Again, we analyse the average growth effect of these independent variables. First, we primarily investigate the impact of indicators on the average growth (from 2007 to 2010) of employment. In our equations, characteristics. In our case, we use stands for the various measures of location-specific sions for subsamples of different firm size classes $(\quad)$, knowledge intensive sectors $(\quad)$ and different age groups ( ) all using the following model:

(1) $\left(\log \left(e m p l_{2010}\right)-\log \left(e m p l_{2007}\right)\right)_{j}=a_{o}+\sum_{k=1}^{5} a_{k} L_{\text {OCATION }}+$ $a \log S I Z E j+a \operatorname{Tog} A G E j+a 8 K I S+\varepsilon$

However, in equation (1) the degree of specialisation of the local knowledge base is still neglected. Since we assume that regional specialisation has an influence on nano-firm, we add the measure as well as its squared term . Thus, we investigate the impact of indicators on the average growth (from 2007 to 2010) of employment:

$$
\begin{gathered}
\left(\log \left(\text { empl }_{2010}\right)-\log \left(\operatorname{empl}_{2007}\right)\right)_{j}=a_{o}+a_{1} L Q_{j}+a_{2} L Q_{j}^{2}+ \\
\sum_{k=3}^{7} a_{k} \text { OCATION }_{k j}+a_{8} \log (S I Z E)_{j}+a_{9} \log (A G E)_{j}+a_{10} K I S+\varepsilon
\end{gathered}
$$

Third, we analyse the robustness of the impact of specialisation and location characteristics on employment growth. Thus, we change the perspective from to a year-to-year consideration of growth. We investigate whether the yearly changes of the level of specialisation might interfere with the yearly changes in the employment growth rates. This means, if growth in one year depends on an increasing level of specialisation or not, the relationship between current employment growth and previous specialisation might be a direct effect or an 
indirect effect. To disentangle this dynamic effect we conduct a cross-sectional time series model. Hence, we estimate firm growth using cross-sectional time series estimation the fixed effects model. In particular, we run the model to gain a more detailed insight on individual characteristics that may contribute to the predictor variable and to control for unknown heterogeneity. To decide whether the fixed effects model is suitable (probably using random effects model), we perform the Hausman test. We do not fail to reject the null hypothesis and conclude that fixed effect model is appropriate (Prob $>$ chi2 is significant). Furthermore, we conduct one regression set for all firms together and then two other regressions for each of and subgroups separately. Hence, our equation (3) follows as:

$$
\log (e m p l)_{i t}=a_{o}+a_{1} L Q_{j}+a_{2} L Q_{j}^{2}+\sum_{k=3}^{7} a_{k} \operatorname{LOCATION}_{k j}+\varepsilon
$$

Finally, we test and control for multicollinearity (see appendix correlation matrix in Table A1) and endogeneity. Moreover, we use the first year value in 2007 (or the first available value) of observation as independent variables in the case of $\mathrm{H} 1$ and $\mathrm{H} 2$ Some of our independent variables are correlated such as and STUD $\left(\mathrm{r}=0.6294^{* * *}\right)$ and and with $\mathrm{r}=0.5931^{* * *}$. represents the share of highly qualified employees with university degree in the region that might be captured by or . Hence, we set up different regression models.

\section{$5 \quad$ Results and Interpretation}

In the following section we will discuss the main findings of the regression analyses and present the interpretation. The regression results are reported in Tables $4-6$.

\subsection{Location characteristics (Hypotheses 1)}

As we want to especially gain information on the location characteristics that contribute to the growth of nano firms, we differentiate between the characteristics of the structure of the region a firm is located in. We assume that

Furthermore

The re-

sults for the regression analysis are presented in Table 4. In our analysis we use the following location-specific characteristics (as described in section 3.3):

and the control variables and . For some of the region-specific character-

istics we find significant results.

In the first step, we find significantly negative coefficients for the of firms. This especially holds for the subsamples of all firms, smaller firms and both subsamples of KIS. Older firms are hence less likely to show higher growth than younger firms, which is in line with the findings of many other scholars before. It can be seen as 'stylized fact' that growth tends to decline with firm age (Audretsch and Dohse 2007). Older firms are characteristically more routinized, more inert and less able to adapt (Coad 2010). In contrast, we find a positive effect of for both knowledge classes and older firms. Against the expectation that firm growth decreases as the firm becomes larger (stylized effect), we find a positive coefficient. The positive coefficients suggest that employment growth tends to increase as the firm becomes larger. 
Table 4: OLS - Employment Growth (EMP)

\begin{tabular}{|c|c|c|c|c|c|c|c|}
\hline Variables & $\begin{array}{c}\text { (I) } \\
\text { All firms } \\
\text { EMP }\end{array}$ & $\begin{array}{c}\text { (II) } \\
\text { SME } \\
\text { EMP } \\
\end{array}$ & $\begin{array}{c}\text { (III) } \\
\text { Large firms } \\
\text { EMP }\end{array}$ & $\begin{array}{l}\text { (IV) } \\
\text { KIS=1 } \\
\text { EMP }\end{array}$ & $\begin{array}{c}(\mathrm{V}) \\
\text { KIS }=0 \\
\text { EMP }\end{array}$ & $\begin{array}{c}(\mathrm{VI}) \\
\text { younger } \\
\text { EMP } \\
\end{array}$ & $\begin{array}{l}\text { (VII) } \\
\text { older } \\
\text { EMP }\end{array}$ \\
\hline HQ & $\begin{array}{l}0.740^{*} \\
(0.922)\end{array}$ & $\begin{array}{l}0.625^{*} \\
(1.391)\end{array}$ & $\begin{array}{c}0.103 \\
(1.018)\end{array}$ & $\begin{array}{l}1.165^{*} \\
(1.079)\end{array}$ & $\begin{array}{l}-1.807 \\
(1.266)\end{array}$ & $\begin{array}{l}4.946^{*} \\
(2.849)\end{array}$ & $\begin{array}{l}0.0566 \\
(0.955)\end{array}$ \\
\hline INDDENS & $\begin{array}{c}0.000759 \\
(0.000857)\end{array}$ & $\begin{array}{c}0.00130 \\
(0.00141)\end{array}$ & $\begin{array}{c}-0.000773 \\
(0.000858)\end{array}$ & $\begin{array}{l}0.000680 \\
(0.00107)\end{array}$ & $\begin{array}{c}0.000786 \\
(0.000937)\end{array}$ & $\begin{array}{l}0.000640 \\
(0.00254)\end{array}$ & $\begin{array}{r}0.000479 \\
(0.000913)\end{array}$ \\
\hline IND & $\begin{array}{l}-3.15 \mathrm{e}-07 \\
(8.48 \mathrm{e}-07)\end{array}$ & $\begin{array}{c}-9.31 \mathrm{e}-08 \\
(1.15 \mathrm{e}-06)\end{array}$ & $\begin{array}{l}-5.38 \mathrm{e}-07 \\
(1.09 \mathrm{e}-06)\end{array}$ & $\begin{array}{l}-2.78 \mathrm{e}-07 \\
(9.12 \mathrm{e}-07)\end{array}$ & $\begin{array}{c}-1.59 \mathrm{e}-05^{* *} \\
(1.15 \mathrm{e}-05)\end{array}$ & $\begin{array}{l}-9.64 \mathrm{e}-06 \\
(2.42 \mathrm{e}-05)\end{array}$ & $\begin{array}{l}-2.25 \mathrm{e}-07 \\
(8.10 \mathrm{e}-07)\end{array}$ \\
\hline STUD & $\begin{array}{c}1.57 \mathrm{e}-07 \\
(1.05 \mathrm{e}-06)\end{array}$ & $\begin{array}{c}-6.88 \mathrm{e}-08 \\
(1.59 \mathrm{e}-06)\end{array}$ & $\begin{array}{c}-4.59 \mathrm{e}-07 \\
(1.15 \mathrm{e}-06)\end{array}$ & $\begin{array}{c}3.91 \mathrm{e}-07 \\
(1.22 \mathrm{e}-06)\end{array}$ & $\begin{array}{c}-2.51 \mathrm{e}-06 * * \\
(1.91 \mathrm{e}-06)\end{array}$ & $\begin{array}{c}1.50 \mathrm{e}-06 \\
(3.38 \mathrm{e}-06)\end{array}$ & $\begin{array}{r}-1.89 \mathrm{e}-07 \\
(1.09 \mathrm{e}-06)\end{array}$ \\
\hline$R \& D$ & $\begin{array}{l}-0.00158 \\
(0.00278)\end{array}$ & $\begin{array}{l}-0.00329 \\
(0.00406)\end{array}$ & $\begin{array}{c}-0.000831 \\
(0.00317)\end{array}$ & $\begin{array}{l}-0.00136 \\
(0.00323)\end{array}$ & $\begin{array}{l}-0.00280^{*} \\
(0.00409)\end{array}$ & $\begin{array}{c}-0.000800 \\
(0.00771)\end{array}$ & $\begin{array}{l}-0.00211 \\
(0.00297)\end{array}$ \\
\hline SIZE & $\begin{array}{l}0.153^{* *} \\
(0.0638)\end{array}$ & & & $\begin{array}{c}0.148^{*} \\
(0.0755)\end{array}$ & $\begin{array}{c}0.162^{*} \\
(0.0872)\end{array}$ & $\begin{array}{c}0.228 \\
(0.268)\end{array}$ & $\begin{array}{c}0.102 \\
(0.0666)\end{array}$ \\
\hline KIS & $\begin{array}{c}0.0121 \\
(0.0814)\end{array}$ & $\begin{array}{c}-0.00628 \\
(0.122)\end{array}$ & $\begin{array}{c}0.0248 \\
(0.0961)\end{array}$ & & & $\begin{array}{l}0.0364 \\
(0.214)\end{array}$ & $\begin{array}{c}0.0162 \\
(0.0897)\end{array}$ \\
\hline AGE & $\begin{array}{c}-0.0701 * * * \\
(0.0263)\end{array}$ & $\begin{array}{l}-0.0844 \\
(0.0563)\end{array}$ & $\begin{array}{l}-0.0197 \\
(0.0325)\end{array}$ & $\begin{array}{c}-0.0702 * * \\
(0.0324)\end{array}$ & $\begin{array}{c}-0.0706^{* * * *} \\
(0.0231)\end{array}$ & & \\
\hline Constant & $\begin{array}{l}0.0155 \\
(0.101)\end{array}$ & $\begin{array}{l}0.408 * * \\
(0.194)\end{array}$ & $\begin{array}{c}0.194 \\
(0.179)\end{array}$ & $\begin{array}{c}0.0213 \\
(0.0920)\end{array}$ & $\begin{array}{c}0.138^{* *} \\
(0.117)\end{array}$ & $\begin{array}{l}0.0181 \\
(0.344)\end{array}$ & $\begin{array}{l}0.0457 \\
(0.108)\end{array}$ \\
\hline Obs. & 216 & 144 & 72 & 178 & 38 & 42 & 174 \\
\hline R-squared & 0.033 & 0.038 & 0.033 & 0.028 & 0.216 & 0.051 & 0.021 \\
\hline
\end{tabular}

More important in the context of our concern is the impact of representing the knowledge intensity in the region. The positive and significant coefficients of highly qualified employees ( ) in the region on the employment growth of all firms points out that firms exhibit higher growth in regions characterised by a share of highly qualified employees in the top quartile. However, this finding does not hold for all subgroups and varies across different firm size classes, and groups. Actually, the coefficient of is significantly positive in smaller firms but not in larger. Thus, the impact of in the region is especially relevant for smaller firms. This might be due to the fact that larger firms are not as much depending on external knowledge and on possible knowledge spillovers stemming from high local endowments in knowledge since they benefit from internal economies of scale in knowledge production as their own knowledge stock is larger. Looking at the results of firms that belong to a knowledge intensive industry (i.e. $=1$ ), we also find a strongly positive significant coefficient. This means firms with high knowledge intensity experience higher employment growth in regions with access to highly qualified employees which is very intuitive. Otherwise and in the case of low-knowledge industry ( ) the coefficient shows no longer a significance. This seems similarly plausible since these firms do not rely as much on knowledge activities and hence regional knowledge endowment is not particularly important. Furthermore, we find another interesting issue concerning the impact of (model VI and VII). We find a positively significant coefficient for firms that are younger than 8 years, but the coefficient is insignificant in case of older firms. This suggests that younger firms experience higher employment growth if they have access to qualified knowledge workers in their region. This finding also goes in line with the general findings by Dosi et al. (1995) and it even more emphasises the relevance of possible knowledge spillovers for new firms that are entering or just entered the nanotechnology-market and its relevance for success in the beginning phase where fundamental knowledge is gained.

Interestingly in the case of low- growth is moreover even negatively influenced by the size of the group of employees that work in the same industry they are engaged in ( ). As the numbers of employees in the same industry also proxies the strength of regional competition, it might indeed especially affect those firms negatively that do not profit as much as others from the positive effects of this concentration, such as (intra-industry) knowledge spillovers. 
Let us now look at the results for the independent variable of representing the common share of R\&D employees in the region. For most of the models we do not receive any significant coefficient. We find a negative and statistically significant coefficient of for

indicating that average employment growth tends to decline with a high share of R\&D employees in the region. While this result might be counterintuitive in the first place, it could be a hint to what we will investigate in our second hypothesis: It is not knowledge that positively influences firm growth, the influence of knowledge and the potentially resulting spillovers depends on the characteristics of the available knowledge. The kind of R\&D processed might e.g. be too basic or to incoherent to be beneficial for firms that are interested in commercialisation. For instance, Frenken et al. (2007) as well as Boschma and Iammarino (2009) refer to such an issue, when they argue that for knowledge to spill over effectively, and hence contribute positively to a firm's performance, related variety in form of complementarities among industries and their knowledge is necessary. Eventually, we are able to entirely confirm H1b.

To sum up, our expectations (hypotheses 1) are strongly confirmed by our results. We confirm that location characteristics can stimulate the growth of firms in nanotechnology. Besides typical impact factors such as and the share of highly qualified employees ( ) does play a major role. We moreover obtain the result that the impact of on firm growth varies across firm size, knowledge intensive industries and age groups. This means, in turn, that the share of highly qualified employees is more important in smaller firms than in larger firms, and seems to be more relevant in firms that are active in particularly knowledge intensive industries. Simultaneously, the impact of is more decisive in younger firms. We hence mostly confirm the findings in the literature that young, small and knowledge intensive firms with access to a high density of knowledge workers do experience an above average growth (Audretsch and Dohse 2007). Thus, nanotechnology firms innovate and grow as other highly knowledge intensive firms do, regardless of the peculiarities a GPT implies. Moreover, nanotechnology firms rely as much on knowledge spillovers as other high-tech (but not GPT) firms from other industries. Finally and most simply, the location-specific measures indicate that the growth of firms in nanotechnology is affected by their location-specific characteristics.

\subsection{Specialisation of the Regional Knowledge Base (Hypotheses 2)}

Remember we suppose that regions that provide knowledge enrich the growth of technologyoriented, i.e. knowledge intensive firms. Since the extent to which external knowledge is crucial and can be absorbed differs widely across different firm size classes and knowledge intensive industries, hypothesis 2 states that

the extent of which we restrict in

linear impact of as states that

We moreover assume a non-

As you can see in Table 5, the independent variable of interest is representing the extent of regional specialisation. Moreover, we also included in order to be able to control for non-linear effects of specialisation. Additionally, we differentiate our sample into different firm size classes ( ), knowledge intensity ( ) as well as age groups ( ).

Table 5: OLS with LQ-variables - Employment Growth (EMP)

\begin{tabular}{lccccccc}
\hline & (I) & (II) & (III) & (IV) & (V) & $(\mathrm{VI})$ & $(\mathrm{VII})$ \\
& All firms & SME & Large firms & KIS=1 & KIS=0 & younger & older \\
Variables & EMP & EMP & EMP & EMP & EMP & EMP & EMP \\
\hline
\end{tabular}




\begin{tabular}{|c|c|c|c|c|c|c|c|}
\hline LQ & $\begin{array}{l}-0.00101 * \\
(0.000572)\end{array}$ & $\begin{array}{c}-0.000738 \\
(0.000858)\end{array}$ & $\begin{array}{c}-0.000923 \\
(0.000630)\end{array}$ & $\begin{array}{l}-0.00126^{*} \\
(0.000684)\end{array}$ & $\begin{array}{l}-0.000408 \\
(0.000955)\end{array}$ & $\begin{array}{l}-0.000788 \\
(0.00171)\end{array}$ & $\begin{array}{l}-0.00121 * * \\
(0.000602)\end{array}$ \\
\hline \multirow[t]{2}{*}{$\mathrm{LQ}^{2}$} & $-8.99 \mathrm{e}-06$ & $-1.06 \mathrm{e}-05$ & $-9.83 e-07$ & $-9.86 e-06$ & $-1.48 \mathrm{e}-05$ & $-2.38 \mathrm{e}-05$ & $-7.23 e-06$ \\
\hline & $(1.12 \mathrm{e}-05)$ & $(1.67 \mathrm{e}-05)$ & $(1.28 \mathrm{e}-05)$ & $(1.34 \mathrm{e}-05)$ & $(1.64 \mathrm{e}-05)$ & $(3.37 \mathrm{e}-05)$ & $(1.19 \mathrm{e}-05)$ \\
\hline \multirow[t]{2}{*}{ HQ } & 1.011 & 0.752 & 0.405 & 1.716 & $-3.028 * * *$ & 5.188 & 0.358 \\
\hline & $(0.943)$ & $(1.433)$ & $(1.043)$ & $(1.123)$ & (1.082) & $(3.188)$ & $(0.967)$ \\
\hline \multirow[t]{2}{*}{ INDDENS } & 0.000657 & 0.00114 & -0.000766 & 0.000530 & 0.000877 & 0.000306 & 0.000350 \\
\hline & $(0.000860)$ & $(0.00143)$ & $(0.000867)$ & $(0.00108)$ & $(0.000963)$ & $(0.00264)$ & $(0.000914)$ \\
\hline \multirow[t]{2}{*}{ IND } & $-2.38 \mathrm{e}-07$ & $-3.35 \mathrm{e}-08$ & $-3.70 e-07$ & $-1.98 \mathrm{e}-07$ & $-1.93 e-05^{*}$ & $-6.62 e-06$ & $-1.71 \mathrm{e}-07$ \\
\hline & $(8.53 \mathrm{e}-07)$ & $(1.17 \mathrm{e}-06)$ & $(1.11 \mathrm{e}-06)$ & $(9.18 \mathrm{e}-07)$ & $(9.84 \mathrm{e}-06)$ & $(2.57 e-05)$ & $(8.13 e-07)$ \\
\hline \multirow[t]{2}{*}{ STUD } & $5.92 \mathrm{e}-07$ & $3.01 \mathrm{e}-07$ & $-1.21 \mathrm{e}-07$ & $1.01 \mathrm{e}-06$ & $-3.67 \mathrm{e}-06^{* *}$ & $2.00 \mathrm{e}-06$ & $2.19 \mathrm{e}-07$ \\
\hline & $(1.09 \mathrm{e}-06)$ & $(1.68 \mathrm{e}-06)$ & $(1.19 \mathrm{e}-06)$ & $(1.28 \mathrm{e}-06)$ & $(1.42 \mathrm{e}-06)$ & $(4.06 \mathrm{e}-06)$ & $(1.11 \mathrm{e}-06)$ \\
\hline \multirow[t]{2}{*}{$R \& D$} & -0.00103 & -0.00308 & $-5.71 e-05$ & -0.000499 & $-0.00589^{*}$ & -0.000145 & -0.00145 \\
\hline & $(0.00282)$ & $(0.00410)$ & $(0.00328)$ & $(0.00330)$ & $(0.00315)$ & $(0.00814)$ & $(0.00300)$ \\
\hline \multirow[t]{2}{*}{ SIZE } & $0.142 * *$ & & & $0.132 *$ & 0.134 & 0.258 & 0.0874 \\
\hline & $(0.0645)$ & & & $(0.0766)$ & $(0.0952)$ & $(0.278)$ & $(0.0675)$ \\
\hline \multirow[t]{2}{*}{ KIS } & 0.0139 & -0.000386 & 0.0315 & & & 0.0655 & 0.0172 \\
\hline & $(0.0827)$ & $(0.126)$ & $(0.0973)$ & & & $(0.230)$ & $(0.0905)$ \\
\hline \multirow[t]{2}{*}{ AGE } & $-0.0677 * *$ & -0.0828 & -0.0231 & $-0.0664 * *$ & $-0.0606^{* *}$ & & \\
\hline & $(0.0265)$ & $(0.0575)$ & $(0.0329)$ & $(0.0328)$ & $(0.0241)$ & & \\
\hline \multirow[t]{2}{*}{ Constant } & 0.0289 & $0.419 * *$ & 0.180 & 0.0322 & 0.190 & 0.0239 & 0.0546 \\
\hline & $(0.105)$ & $(0.201)$ & $(0.187)$ & $(0.104)$ & $(0.134)$ & $(0.354)$ & $(0.113)$ \\
\hline Obs. & 216 & 144 & 72 & 178 & 38 & 42 & 174 \\
\hline R-squared & 0.045 & 0.042 & 0.059 & 0.043 & 0.238 & 0.065 & 0.041 \\
\hline
\end{tabular}

As model I in Table 5 shows, the coefficient of does appear significant with a negative sign. This clearly indicates that specialisation in any application field of general purpose nanotechnology can has an overall negative impact on the growth of nano-firms in terms of employment. This is a hint to the fact that specialisation is counterproductive for explorative, knowledge intensive purpose in the GPT field under investigation here. Specialisation suppresses multiple opportunities for nanotechnology as GPT to develop and inhibits possibilities of catalysing effects and cross fertilisation. The differentiation into different subgroups emphasises that, however, this effect differs across different firm characteristics: The results for the independent variable of are still significantly negative for high-KIS and older firms (see Table 5: model IV and VII). These are the firms that are especially prone to exploitation activities since they are knowledge-intensive. It might hence be the case that knowledge intensive firms explore the nano-field as their flexibility of thinking might make it more easy for these firms to perceive possibilities of application of old nano-knowledge in new fields. Another interesting issue is that shows statistically insignificant coefficients, except in the case of low-KIS. An explanation for this issue might be that is captured by the specialisation measures. We also know from Table A1 that and are correlated with each other $\left(\mathrm{r}=0.2296^{* * *}\right)$. In the case of low-KIS we even find a strong significant coefficient with a negative sign. We interpret this as a statistical support for the fact that firms where knowledge is not a crucial driver of employment growth depend less on highly qualified employees (as knowledge sources) in the region.

Since specialisation suppresses exploration (e.g. Greve 2007) this explains the negative influence of specialisation on employment growth. Older firms already survived the critical startup phase and moreover are more prone to possessing the necessary endowment with resources to further explore the field. For the other subsamples such as differentiation across and or younger firms, no significant effect of specialisation can be found. This is contrary to our expectation that especially young and small firm benefit from specialisation since they occupy mostly specialised niches when entering the market. This is why can be confirmed and cannot.

In order to test we also included the squared form of in the model. Our results suggest that too much specialisation does not have any influence on the employment growth in firms active in nanotechnologies except for the case of low-KIS firms where too much spe- 
cialisation and too much anti-specialisation, in contrast to moderate specialisation is harmful. Although generally specialisation of the regional knowledge base has no impact on a firm's performance, employment growth declines when the region becomes too specialised. Since this does only hold for one particular case, cannot be confirmed here. This might be due to the fact that specialisation in general already is counterproductive to the firms' employment growth. This effect does not seem to become more serious with increasing specialisation.

Summarising, we hence state that regional specialisation does have a mostly negative impact on nano-firm employment growth, even though not for all firms similarly but depending on their knowledge processing characteristics. Hypotheses 2 can therefore be confirmed in general means.

\subsection{Robustness of the Impact of Specialisation (Hypothesis 3)}

In a last step, we analyse the robustness of the impact of specialisation and the location characteristics on growth. We try to highlight the fact whether yearly changes of the level of specialisation might interfere with yearly changes in the employment growth rates. This means, if growth in one year depends on an increasing level of specialisation, the relationship between current employment growth and previous specialisation might be a direct effect. To disentangle this dynamic effect we conduct regressions where we include the different measures of specialisation and the different measures. Hence, we hypothesise that

Table 6 presents the detailed regression results for the fixed effects model. Again, Table A1 clearly presents that and $\quad(r=-0.4078)$ are correlated. We already stated in hypothesis 1 that firms in nanotechnology are affected by location-specific characteristics (e.g. , $\quad$ ). Thus, we neglect most of these indicators because in this analysis it is beyond the scope to analyse the pure impact of location again. Now we only consider the more particular impact of the level of specialisation. The findings vary (see Table 6).

Table 6: Cross-sectional Time Series - Fixed Effects Model for Employment Growth (EMP)

\begin{tabular}{|c|c|c|c|c|c|c|c|}
\hline Variables & $\begin{array}{l}\text { (I) } \\
\text { All firms } \\
\text { EMP } \\
\end{array}$ & $\begin{array}{l}\text { (II) } \\
\text { SME } \\
\text { EMP } \\
\end{array}$ & $\begin{array}{c}\text { (III) } \\
\text { Larger firms } \\
\text { EMP } \\
\end{array}$ & $\begin{array}{c}(\mathrm{IV}) \\
\mathrm{KIS}=1 \\
\mathrm{EMP}\end{array}$ & $\begin{array}{c}(\mathrm{V}) \\
\mathrm{KIS}=0 \\
\mathrm{EMP}\end{array}$ & $\begin{array}{c}(\mathrm{VI}) \\
\text { Younger } \\
\text { EMP } \\
\end{array}$ & $\begin{array}{l}\text { (VII) } \\
\text { older } \\
\text { EMP }\end{array}$ \\
\hline LQ & $\begin{array}{l}-0.00255 \\
(0.00181)\end{array}$ & $\begin{array}{l}-0.00308 \\
(0.00217)\end{array}$ & $\begin{array}{c}0.00293 \\
(0.00276)\end{array}$ & $\begin{array}{l}-0.00318 \\
(0.00199)\end{array}$ & $\begin{array}{c}0.00214 \\
(0.00557)\end{array}$ & $\begin{array}{l}0.000888 \\
(0.00823)\end{array}$ & $\begin{array}{l}0.000158 \\
(0.00167)\end{array}$ \\
\hline $\mathrm{LQ}^{2}$ & $\begin{array}{l}-3.14 \mathrm{e}-05^{*} \\
(1.67 \mathrm{e}-05)\end{array}$ & $\begin{array}{c}-4.13 \mathrm{e}-05^{* *} \\
(2.02 \mathrm{e}-05)\end{array}$ & $\begin{array}{c}2.18 \mathrm{e}-05 \\
(2.36 \mathrm{e}-05)\end{array}$ & $\begin{array}{l}-3.37 e-05^{*} \\
(1.79 e-05)\end{array}$ & $\begin{array}{c}9.27 \mathrm{e}-06 \\
(5.99 \mathrm{e}-05)\end{array}$ & $\begin{array}{l}-0.000142 \\
(8.71 \mathrm{e}-05)\end{array}$ & $\begin{array}{l}-7.05 \mathrm{e}-07 \\
(1.50 \mathrm{e}-05)\end{array}$ \\
\hline HQ & $\begin{array}{c}1.551^{* * *} \\
(0.283)\end{array}$ & $\begin{array}{c}2.328 * * * \\
(0.404)\end{array}$ & $\begin{array}{c}0.366 \\
(0.242)\end{array}$ & $\begin{array}{c}1.476 * * * \\
(0.328)\end{array}$ & $\begin{array}{c}1.902 * * * \\
(0.527)\end{array}$ & $\begin{array}{c}2.719 * * \\
(1.266)\end{array}$ & $\begin{array}{c}1.223 * * * \\
(0.228)\end{array}$ \\
\hline INDDENS & $\begin{array}{c}0.00463 \\
(0.00809)\end{array}$ & $\begin{array}{c}0.000657 \\
(0.0120)\end{array}$ & $\begin{array}{c}0.00504 \\
(0.00643)\end{array}$ & $\begin{array}{c}0.00105 \\
(0.00916)\end{array}$ & $\begin{array}{c}0.0204 \\
(0.0164)\end{array}$ & $\begin{array}{l}0.00253 \\
(0.0351)\end{array}$ & $\begin{array}{c}0.00528 \\
(0.00652)\end{array}$ \\
\hline IND & $\begin{array}{l}-1.09 \mathrm{e}-05 \\
(2.76 \mathrm{e}-05)\end{array}$ & $\begin{array}{l}-3.83 \mathrm{e}-05 \\
(3.98 \mathrm{e}-05)\end{array}$ & $\begin{array}{l}-2.78 \mathrm{e}-05 \\
(2.46 \mathrm{e}-05)\end{array}$ & $\begin{array}{c}3.26 \mathrm{e}-06 \\
(3.07 \mathrm{e}-05)\end{array}$ & $\begin{array}{l}-0.000100 \\
(6.55 \mathrm{e}-05)\end{array}$ & $\begin{array}{c}3.48 \mathrm{e}-05 \\
(0.000168)\end{array}$ & $\begin{array}{l}-2.79 \mathrm{e}-05 \\
(2.17 \mathrm{e}-05)\end{array}$ \\
\hline Constant & $\begin{array}{c}8.224 * * * \\
(0.791)\end{array}$ & $\begin{array}{c}8.388 * * * \\
(1.148)\end{array}$ & $\begin{array}{c}9.505 * * * \\
(0.664)\end{array}$ & $\begin{array}{c}8.106 * * * \\
(0.902)\end{array}$ & $\begin{array}{c}8.694 * * * \\
(1.631)\end{array}$ & $\begin{array}{l}8.705 * * \\
(3.731)\end{array}$ & $\begin{array}{c}8.097 * * * \\
(0.631)\end{array}$ \\
\hline Obs. & 652 & 429 & 223 & 538 & 114 & 131 & 521 \\
\hline R-squared & 0.076 & 0.125 & 0.026 & 0.070 & 0.173 & 0.131 & 0.078 \\
\hline Number of id & 652 & 429 & 223 & 538 & 114 & 131 & 521 \\
\hline
\end{tabular}

We start our discussion with a comparison between the firm characteristics that relate to average growth $(\mathrm{H} 2)$ and the firm characteristics that relate to a year-to-year consideration $(\mathrm{H} 3)$. As a result, if we change the perspective from average growth to a year-to-year consideration, we receive different results in the case of all subsamples. Obviously, the coefficients for 
never become significant. First, if we look at the results for all firms together, we find no longer a negative coefficient for . What we find is a significant negative coefficient for in the overall model I and the two subsamples of high-KIS and small firms. We interpret this as a statistical support for the fact that employment growth tends to decline with very low and very high levels of specialisation. Put differently, specialisation hampers year-to-year employment growth of local firms if a certain threshold of specialisation is undercut or exceeded. Also in these cases the effect of the average growth path is not confirmed for the year-to-year perspective. For the year-to-year consideration, our results suggest that specialisation indeed influences firm employment growth in a non-linear way (see Table 6). While the marginal effect of specialisation is initially insignificant, it becomes significant and negative for regions that exhibit extreme values of specialisation. This means although generally specialisation of the regional knowledge base has no impact on a firm's performance, employment growth declines when the region becomes too much or too less specialised. Even though there is no general positive effect for lower levels of specialisation this reminds us of an inverted ushaped relationship between specialisation and performance often found in empirical work on production (Betrán 2011) stating that too much (or to less) specialisation has a negative influence on performance.

Generally spoken, this model does not confirm the results of the OLS regressions (average growth) around hypotheses 2 . Hence, the results contradict what we expected in hypothesis 3 , which is why we have to reject it. The characteristics that come together with average growth are not usually related to occurrence of year-to-year growth. However, an analysis of the yearto-year growth process of nano-firms provides additional information, as discussed above. If we change the perspective from average growth to year-to-year consideration the findings vary. Hence, the temporal structure of the growth process itself should be considered. And what is most important in terms of our initial questions: We never find a positive impact of specialisation on the employment growth of nano-firms. Referring to the prevailing of hightech of GPT features referring to the relevance of the surrounding, GPT features seem to outweigh high-tech ones - although further empirical investigation needs to be done to disentangle the concrete effects of specialisation on firm growth in high - and nanotechnologies.

\section{Conclusion}

Nanotechnology firms' growth is influenced by the locations that host the firms. More particularly, we examined whether the local endowment with knowledge influences the growth of these firms. As we expected in view of nanotechnology firms operating on an innovation and hence knowledge intensive high technology field, the performance of these firms is - in general - stimulated by the local access to (high) knowledge. However, the actual impact of knowledge varies across firms with different characteristics. While the share of highly qualified employees never hampers growth (although it seems not to advance it either in e.g. larger firms), the local stock of employees concerned with R\&D indeed has a hampering effect. We interpret this as a hint to the necessity of the knowledge to be marketable. However, this might also be interpreted as the inefficiency of knowledge transfer from universities to technology. Finally, knowledge is as relevant for nanotechnology firms as for other highly knowledge intensive firms, regardless of the peculiarities a GPT implies: Nanotechnology firms rely as much on knowledge spillovers as other high-tech (but not GPT) firms from other industries. The impact, however, depends on knowledge processing characteristics like it is the case in other industries.

Moreover, the impact of knowledge for nano-firm growth also depends on the characteristics of knowledge itself. We set out to investigate the special influence of specialisation of the regional knowledge base. When analysing average employment growth rates, the impact of 
specialisation is counterproductive to some firms, it has no effect on growth in others. In the year-to-year consideration, however, regional specialisation only has a negative effect in extreme situations. Although these results differ, it becomes clear that specialisation does not have a positive effect on firm growth in nanotechnology. The relevance of these effects has, however, to be seen in context with the special characteristics of GPTs, which develop their positive and accelerating effect on growth in a setting that is open to exploration and crossapplication (which is not supported by specialisation). These findings point to the importance of our study: Although it is popular among policymakers to support the establishment of specialised nano-clusters, our results suggest that this regional specialisation is not conducive for the firms. Moreover, it might even become a burden for the performance of some firms, depending on the local degree of specialisation and the firm's knowledge processing characteristics. However, our findings are relying on a small number of firms in nanotechnology only. Moreover, the indicators on the impact of local knowledge resources, such as and could be refined (e.g. disentangling relevant STUD and R\&D, such as students in technological fields) in order to be able to further investigate local knowledge is relevant. Further research should also be done on the effect of specialisation in a larger sample or other (GPT) settings to confirm these results, especially in view of findings that state a positive effect of specialisation for many other, but different circumstances and industries. It moreover lies beyond the scope of this paper to investigate the mechanisms behind our findings. It would be interesting to learn how exactly local knowledge is processed, where spillovers indeed are effective and how specialisation exactly affects innovation in high-technologies.

The conclusion of this paper remains that local knowledge endowment indeed positively influences firm growth in nanotechnology, while local knowledge specialisation surely is not always positively affecting the growth of individual firms, pointing to the relevance of the GPT feature of nanotechnology for processing knowledge in firms.

\section{Acknowledgements}

We thank Dirk Dohse and the participants of the DRUID Academy 2012 in Cambridge for helpful comments as well as the Karlsruhe House of Young Scientists and the German National Academic Foundation for financial support.

\section{References}

Acs, Z. J. and Audretsch, D. B. (1988): Innovation and firm size in manufacturing, Technovation, Vol. 7, pp. 197-201.

Acs, Z. J. and Audretsch, D. B. (1990): Innovation and Small Firms, MIT Press, Cambridge MA.

Adamou, A. and Sasidharan, S. (2007): The impact of R\&D and FDI on firm growth in emerging-developing countries: Evidence from Indian manufacturing industries, Working Paper 37, Madras School of Economic Policy, Madras.

Audretsch, D. (1998): Agglomeration and the location of innovative activity, Oxford Review of Economic Policy, Vol. 14(2), pp. 18-29.

Audretsch, D. B. and Dohse, D. (2007): Location: A neglected determinant of firm growth, Review of World Economics, Vol. 143(1), pp. 79-107.

Betrán, C. (2011): Regional specialization and industry location in the long run: Spain in the US mirror (1856-2002), Cliometrica, Vol. 5, pp. 259-290. 
Boschma, R. A. and Weterings, A. B. R. (2005): The effect of regional differences on the performance of software firms in the Netherlands, Journal of Economic Geography, Vol. 5, pp. 567- 588 .

Boschma, R. and Iammarino, S. (2009): Related Variety, Trade Linkages, and Regional Growth in Italy, Economic Geography, Vol. 85, pp. 289-311.

Coad, A. (2007): Understanding the processes of firm Growth - A closer look at serial growth rate correlation, Review of Industrial Organization, Vol. 31, pp. 69-82.

Coad, A. (2010): Investigating the exponential age distribution of firms, Economics: The Open-Access, Open-Assessment E-Journal, Vol. 4, pp. 2010-17.

Coad, A. and Rao, R. (2008): Innovation and firm growth in high-tech sectors: A quantile regression approach, Research Policy, Vol. 37(4), pp. 633-648.

Coase, R. H. (1937): The nature of the firm, Economica, Vol. 4, pp. 386-405.

Cohen, W. and Levinthal, D. (1990): Absorptive capacity: A new perspective on learning and innovation, Administrative Science Quarterly, Vol. 35(1), pp. 128-152.

Del Monte, A. and Papagni, E. (2003): R\&D and the growth of firms: Empirical analysis of a panel of Italian firms, Research Policy, Vol. 32(6), pp. 1003-1014.

Delmar, F., Davidsson, P. and Gartner, W. (2003): Arriving at the high-growth firm, Journal of Business Venturing, Vol. 18(2), pp. 189-216.

Dosi, G., Marsili, O., Orsenigo, L., and Salvatore, R. (1995): Learning, Market Selection and the Evolution of Industrial Structures, Small Business Economics, Vol. 7(6), pp. 411436.

Fagiolo, G., and Luzzi, A. (2006): Do Liquidity Constraints Matter in Explaining Firm Size and Growth? Some Evidence from the Italian Manufacturing Industry, Industrial and Corporate Change, Vol. 15(1), pp. 1-39.

Feldman, M. and Audretsch, D. (1999): Innovation in cities: Science-based diversity, specialization and localized competition, European Economic Review, Vol. 43, pp. 409-429.

Feldman, M. and Kogler, D. (2010): Stylized facts in the geography of innovation, Handbook of the Economics of Innovation, Oxford University Press, chapter 8, pp. 381-410.

Feldman, M. P. (1994): The Geography of Innovation, Springer, Boston.

Frenken, K., van Oort, F., and Verburg, T. (2007): Related Variety, Unrelated Variety and Regional Economic Growth, Regional Studies, Vol. 41, pp. 685-697.

Fritsch, M. and Slavtchev, V. (2008): Industry specialization, diversity and the efficiency of Regional Innovation Systems, in C. van Beers, A. Kleinknecht, R. Ortt and R. Verburg (eds), Determinants of Innovative Behaviour. A Firm's Internal Practices and its External Environment, Palgrave Macmillan, New York, pp. 272-293.

Fritsch, M. and Slavtchev, V. (2010): How does industry specialization affect the efficiency of regional innovation systems?, The Annals of Regional Science, Vol. 45(1), pp. 87108.

Fromhold-Eisebith, M. and Eisebith, G.: 2005, How to institutionalize innovative clusters? Comparing explicit top-down and implicit bottom-up approaches, Research Policy, Vol. 34(8), pp. 1250-1268.

Gabe, T. M. and Kraybill, D. S. (2002): The effect of state economic development incentives on employment growth of establishments, Journal of Regional Science, Vol. 42(4), pp. 703-730.

Garnsey, E., Stam, E. and Heffernan, P. (2006): New Firm Growth: Exploring Processes and Paths, Industry and Innovation, Vol. 13(1), pp. 1-20.

Greve, H. (2007): Exploration and exploitation in product innovation, Industrial and Corprate Change, Vol. 16(5), pp. 945-975.

Harhoff, D., Stahl, K. and Woywode, M. (1998): Legal form, growth and exit of west German firms - empirical results for manufacturing, construction, trade and service industries, Journal of Industrial Economics, Vol. 46(4), pp. 453-88. 
Harrison, R., Jaumandreu, J., Mairesse, J. and Peters, B. (2008): Does innovation stimulate employment? a firm-level analysis using comparable micro-data from four European countries, Working Paper 14216, National Bureau of Economic Research. URL: http://www.nber.org/papers/w14216.

Huergo, E., and Jaumandreu, J. (2004b). How does probability of innovation change with firm age? Small Business Economics, Vol. 22(3), pp. 193-207.

Jovanovic, B. (1982): Selection and the Evolution of industry, Econometrica, Vol. 50 Issue 3, pp. 649-670.

Ketels, C. (2009): Clusters, cluster policy, and Swedish competitiveness in the global economy, Expert Report 30, The Globalisation Council.

Leten, B., Belderbos, R., and van Looy, B. (2007): Technological diversification, coherence and performance of firms, Journal of Product Innovation Management, Vol. 24(6), pp. $567-579$.

López-García, P. and Puente, S. (2009): What makes a high-growth firm? A probit analysis using Spanish firm level data, Banco de España Working Paper 0920.

Martin, R. and Sunley, P.: 2003, Deconstructing clusters: Chaotic concept or policy panacea, Journal of Economic Geography, Vol. 3(1), pp. 5-35.

Moreno, R., Paci, R. and Usai, S. (2004): Geographical and sectoral clusters of innovation in Europe, Working Paper 15, CRENoS, Centro Richerche Economiche Nord Sud.

Paci, R. and Usai, S. (1999): Externalities, knowledge spillovers and the spatial distribution of innovation, GeoJournal, Vol. 49, pp. 381-390.

Penrose, E. (1995): The Theory of the Growth of the Firm, Oxford University Press, Oxford.

Pianta, M. (2005): Innovation and employment, in J. Fagerberg, D. Mowery and R. Nelson (eds), The Oxford Handbook of Innovation, Oxford University Press, pp. 568-598.

Porter, M. (2000): Locations, clusters and company strategy, in G. L. Clark, M. P. Feldman and M. S. Gertler (eds), The Oxford Handbook of Economic Geography, Oxford University Press, Oxford, pp. 253-274.

Reynolds, P., Storey, D., and Westhead, P. (1994): Cross-national comparisons of the variation in new firm formation rates, Regional Studies, Vol. 28(4), pp. 443-456.

Rigby, D. and Essletzbichler, J. (2002): Agglomeration and productivity differences in US cities, Journal of Economic Geography, Vol. 2, pp. 407-432.

Schnorr-Bäcker, S. (2009): Nanotechnologie in der amtlichen Statistik, Statistisches Bundesamt, Wirtschaft und Statistik, Vol. 3, pp. 209-215.

Storey, D. J.: 1994, Understanding the Small Business Sector, Thomson Business Press, London.

Uhlaner, L., Wright, M. and Huse, M. (2007): Private firms and corporate governance: An integrated economic and management perspective, Small Business Economics, Vol. 29(3), pp. 225-241.

van der Panne, G. (2004): Agglomeration externalities: Marshall vs. Jacobs, Journal of Evolutionary Economics, Vol. 14, pp. 593-604.

von Hippel, E. (1994): "Sticky Information" and the locus of problem solving: Implications for innovation, Management Science, Vol. 40(4), pp. 429-439.

Weterings, A. and Boschma, R.: 2009, Does spatial proximity to customers matter for innovative performance? Evidence from the Dutch software sector, Research Policy, Vol. 38(5), pp. 746-755.

Youtie, J., Iacopetta, M. and Graham, S. (2008): Assessing the nature of nanotechnology: Can we uncover an emerging general purpose technology? Journal of Technology Transfer, Vol. 33, pp. 315-329. 


\section{Appendix}

Table A1: Correlation Matrix

\begin{tabular}{|c|c|c|c|c|c|c|c|c|c|c|c|}
\hline & EMP & $\begin{array}{l}\mathrm{HQ} \\
\end{array}$ & INDDENS & IND & STUD & R\&D & LQ & $\mathrm{LQ}^{2}$ & SIZE & KIS & AGE \\
\hline $\begin{array}{l}\text { EMP } \\
\text { HQ }\end{array}$ & $\begin{array}{c}1.0000 \\
0.0573(0.4020)\end{array}$ & 1.0000 & & & & & & & & & \\
\hline INDDENS & $0.0482(0.4809)$ & $0.3720(0.0000)$ & 1.0000 & & & & & & & & \\
\hline IND & $-0.0343(0.6160)$ & $-0.0793(0.2260)$ & $-0.0584(0.3726)$ & 1.0000 & & & & & & & \\
\hline STUD & $0.0165(0.8092)$ & $0.6294(0.0000)$ & $0.4509(0.0000)$ & $-0.0936(0.1527)$ & 1.0000 & & & & & & \\
\hline R\&D & $-0.0509(0.4567)$ & $0.5931(0.0000)$ & $0.0989(0.1299)$ & $0.0069(0.9162)$ & $0.2374(0.0002)$ & 1.0000 & & & & & \\
\hline LQ & $-0.1074(0.1164)$ & $0.2296(0.0004)$ & $0.0195(0.7670)$ & $-0.0005(0.9945)$ & $0.1924(0.0031)$ & $0.2309(0.0004)$ & 1.0000 & & & & \\
\hline $\mathrm{LQ}^{2}$ & $-0.0214(0.7552)$ & $-0.1158(0.0770)$ & $-0.0186(0.7777)$ & $-0.0794(0.2261)$ & $0.0389(0.5542)$ & $-0.0541(0.4098)$ & $-0.4078(0.0000)$ & 1.0000 & & & \\
\hline SIZE & $0.1632(0.0163)$ & $-0.1130(0.0832)$ & $-0.1324(0.0422)$ & $-0.0183(0.7802)$ & $-0.1192(0.0676)$ & $-0.1142(0.0800)$ & $-0.0656(0.3174)$ & $-0.0599(0.3620)$ & 1.0000 & & \\
\hline KIS & $0.1624(. .0172)$ & $0.1646(0.0117)$ & $0.0169(0.7973)$ & $-0.0054(0.9347)$ & $-0.0054(0.9347)$ & $0.2196(0.0007)$ & $0.0638(0.3308)$ & $0.1095(0.0946)$ & $0.1457(0.0258)$ & 1.0000 & \\
\hline AGE & $-0.1922(0.0056)$ & $-0.0240(0.7224)$ & $-0.0560(0.4065)$ & $0.0666(0.3245)$ & $0.0142(0.8339)$ & $0.0481(0.4760)$ & $0.0497(0.4633)$ & $0.0289(0.6700)$ & $-0.1420(0.0353)$ & $0.0055(0.9333)$ & 1.0000 \\
\hline
\end{tabular}

Table A2: Descriptive Statistics

\begin{tabular}{lcrrrr}
\hline Variable & Obs. & \multicolumn{1}{c}{ Mean } & Std. Dev. & \multicolumn{1}{c}{ Min } & \multicolumn{1}{c}{ Max } \\
\hline \hline EMP & 216 & 0.1398783 & 0.4411129 & -3.610918 & 1.633717 \\
KIS & 236 & 0.8177966 & 0.3868325 & 0 & 1 \\
SME & 236 & 0.6313559 & 0.4834625 & 0 & 1 \\
AGE & 222 & 3.000362 & 1.200884 & 0 & 5.83773 \\
HQ & 236 & 0.1150768 & 0.0354213 & 0.0472828 & 0.1844673 \\
INDDENS & 236 & 45.43375 & 39.07808 & 2.165327 & 165.8995 \\
IND & 235 & 8001.506 & 34290.28 & 1 & 437500 \\
STUD & 236 & 38148.5 & 33889.06 & 0 & 134260.4 \\
R\&D & 236 & 9112.375 & 11739.87 & 140.1972 & 39878.7 \\
RTAN & 234 & -6.953736 & 58.34249 & -100 & 99.47198 \\
LQ & 234 & -5.342925 & 58.55617 & -100 & 99.46871 \\
\hline \hline
\end{tabular}




\section{Working Paper Series in Economics}

recent issues

No. 38 Antje Schimke, Nina Teichert, Ingrid Ott: Impact of local knowledge endowment on employment growth in nanotechnology, February 2012

No. 37 Siegfried K. Berninghaus, Lora Todorova, Bodo Vogt: A simple questionnaire can change everything - are strategy choices in coordination games stable?, December 2011

No. 36 Matthias Duschl, Antje Schimke, Thomas Brenner, Dennis Luxen: Firm growth and the spatial impact of geolocated external factors - empirical evidence for German manufacturing firms, November 2011

No. 35 Mirja Meyborg: The impact of West-German universities on regional innovation activities - a social network analysis, October 2011

No. 34 Tom Broekel, Antje Schimke, Thomas Brenner: The effect of cooperative R\&D subsidies and subsidized cooperation on employment growth, October 2011

No. 33 Stephan Schosser and Bodo Vogt: The public loss game - an experimental study of public bads, August 2011

No. 32 Antje Schimke and Thomas Brenner: Temporal structure of firm growth and the impact of R\&D, July 2011

No. 31 Axel Schaffer: Appropriate policy measures to attract private capital in consideration of regional efficiency in using infrastructure and human capital, July 2011

No. 30 Stoyan V. Stoyanov, Svetlozar T. Rachev, Boryana Racheva-lotova, Frank J. Fabozzi: Fat-tailed models for risk estimation, May 2011

No. 29 Stoyan V. Stoyanov, Svetlozar T. Rachev, Frank J. Fabozzi: CVaR sensitivity with respect to tail thickness, May 2011 